\title{
Th/U and U series systematics of saprolite: importance for the oceanic ${ }^{234} \mathrm{U}$ excess
}

\author{
N. Suhr1*, M. Widdowson², F. McDermott ${ }^{3,4}$, B.S. Kamber ${ }^{1}$
}

Abstract

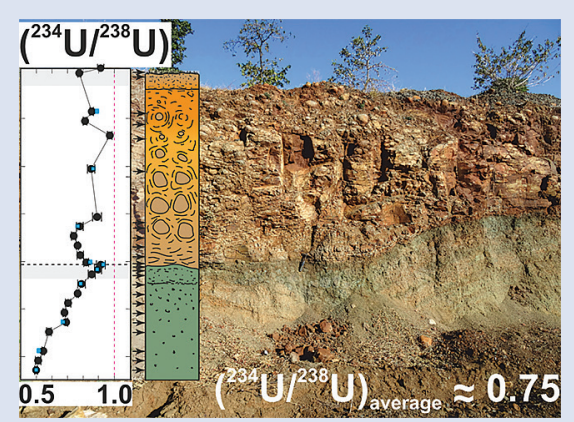

The presence of excess ${ }^{234} \mathrm{U}$ in seawater is a compelling argument for active delivery of solutes from the continents to the oceans. Previous studies found, however, that the complementary ${ }^{234} \mathrm{U}$ deficit on the continents is surprisingly modest, which would require protracted U loss from a large continental weathering pool. Our new compilation and statistical analysis of the published data, coupled with a mass balance calculation demonstrates that the apparent small ${ }^{234} \mathrm{U}$ deficit in the continental weathering pool implied by previous studies is insufficient to balance the observed oceanic excess. Our new data for a saprolite weathering profile developed on Deccan basalt reveal a very strong overall loss of $U$ (elevated $T h / U$ ) with a strong ${ }^{234} U$ deficit attributable to chemical weathering. The $U$ and ${ }^{234} U$ deficits reported here from a geologically recent saprolite confirm the importance of the early stages of chemical weathering at the weathering front in the supply of nutrients to the oceans. Thus, as much as half the oceanic ${ }^{234} \mathrm{U}$ inventory is likely sourced from a thin active saprolite zone.

Received 24 August 2017 | Accepted 26 January 2018 | Published 14 February 2018

\section{Introduction}

One of the strongest pieces of evidence for active and ongoing delivery of chemical elements from the continents to the oceans is the presence of ${ }^{234} \mathrm{U}$ excess in seawater. The elevated $\left({ }^{234} \mathrm{U} /{ }^{238} \mathrm{U}\right)$ of seawater $(\sim 1.145)$, coupled with its relatively high $\mathrm{U}$ concentration and constancy of $\left({ }^{234} \mathrm{U} /{ }^{238} \mathrm{U}\right)$ over $>780 \mathrm{kyr}$ (Henderson, 2002) requires a continuous, quasi-steady input of $U$ to the oceans. On long time scales, since the rise of free atmospheric oxygen, ca. 2.35 Gyr ago (Bekker et al., 2004) significant fluvial transport of soluble oxidised U(VI) from the continents to the oceans has occurred. The loss of $U$ from the terrestrial realm to the oceans is primarily a consequence of rock weathering and is apparent from many lines of evidence (e.g., Partin et al., 2013).

The global mean $\left({ }^{234} \mathrm{U} /{ }^{238} \mathrm{U}\right)$ of dissolved river water $\mathrm{U}$ lies between 1.17-1.26 (Chabaux et al., 2001; Dunk et al., 2002). Excess ${ }^{234} \mathrm{U}$ in rivers and seawater implies that a corresponding deficit should exist through concomitant depletion within the weathered land surface. The short-lived nature of ${ }^{234} \mathrm{U}$, the relatively short residence time of dissolved $U$ in the oceans (300-500 kyr; Dunk et al., 2002) and the long-term stability of seawater $\left({ }^{234} \mathrm{U} /{ }^{238} \mathrm{U}\right)$ (Henderson, 2002) implies a steady release of $U$ from continental weathering zones.

Here we present the first comprehensive compilation of data for terrestrial weathering products measured for U series systematics (Fig. 1a) and calculate a mean global $\left({ }^{234} \mathrm{U} /{ }^{238} \mathrm{U}\right)$ of $0.992 \pm 0.096(1 \sigma)$ (Table S-1; Supplementary Information). The dispersion around the mean results from the large number of samples of weathering residues $(n=335)$ from different climatic and hydrological conditions. Regardless, statistical analysis shows that at the confidence level of $95 \%$, the data are tightly distributed (0.992 \pm 0.010 ; Eq. S-1) and that the mode is also close to secular equilibrium (1.04). The percentage cumulative frequency distribution (Fig. S-1) shows that the calculated average $\left({ }^{234} \mathrm{U} /{ }^{238} \mathrm{U}\right)$ of 0.992 is not skewed by outliers with unusually high $\left({ }^{234} \mathrm{U} /{ }^{238} \mathrm{U}\right)$ and that there is no indication that it should not be representative of the global mean terrestrial weathering residue. At face value, this close-to-equilibrium ratio suggests that the average weathering residue records only a modest ${ }^{234} \mathrm{U}$ loss, which, in turn, would imply that a very large mass of Earth surface material losing only a small fraction of its $U$ at a slow rate.

However, soils with consistently low $\left({ }^{234} \mathrm{U} /{ }^{238} \mathrm{U}\right)$ values $\leq 0.90-0.55$ ( $n=20$ samples) (Rosholt et al., 1966; Mathieu et al., 1995) (Fig. 1a) do exist, and at least regionally, very strong U loss at high chemical weathering rates has been documented for the last 7-40 kyr (Ma et al., 2010). Thus, locally, rapid loss of $U$ during active weathering does occur within the critical zone (CZ) and this may not be fully captured by the global mean $\left.{ }^{234} \mathrm{U} /{ }^{238} \mathrm{U}\right)$ from previous studies of weathering residues (Fig. 1a).

\footnotetext{
1. Department of Geology, School of Natural Sciences, Trinity College, Dublin, Ireland

* Corresponding author (email: nsuhr@tcd.ie)

2. Department of Geography, Environment and Earth Sciences, University of Hull, Cottingham Road, Hull, HU6 7RX, UK

3. UCD School of Earth Sciences, University College Dublin, Belfield, Dublin 4, Ireland

4. UCD Earth Institute, University College Dublin, Belfield, Dublin 4, Ireland
} 
Previous studies on weathering profiles

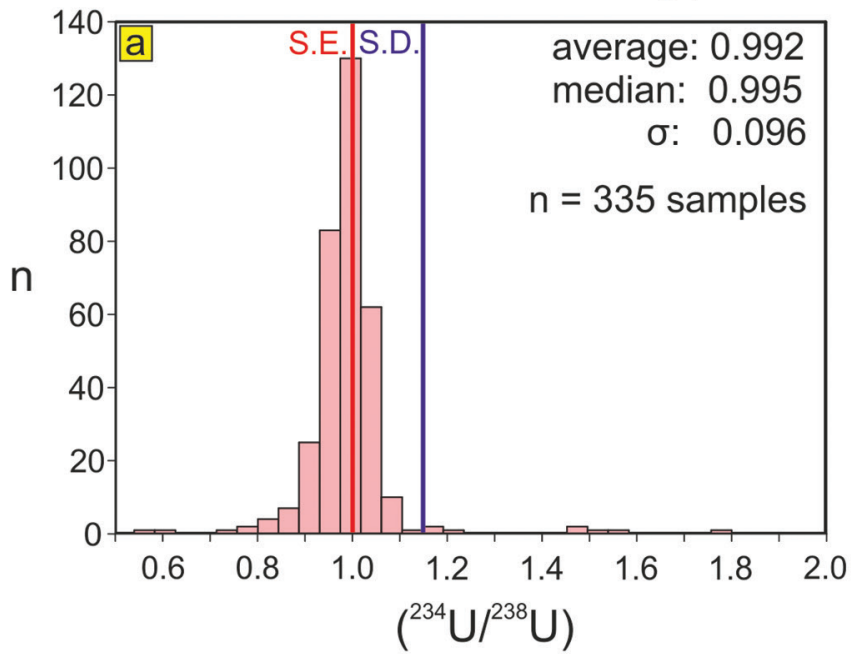

Rivers: dissolved load

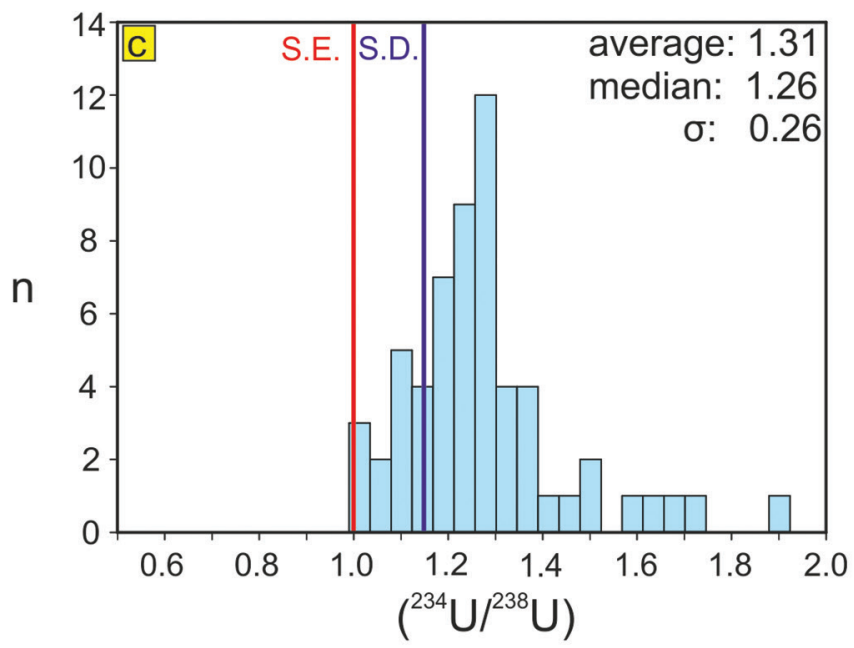

Residual weathered upper crust required to balance excess ${ }^{234} \mathrm{U}$ in seawater

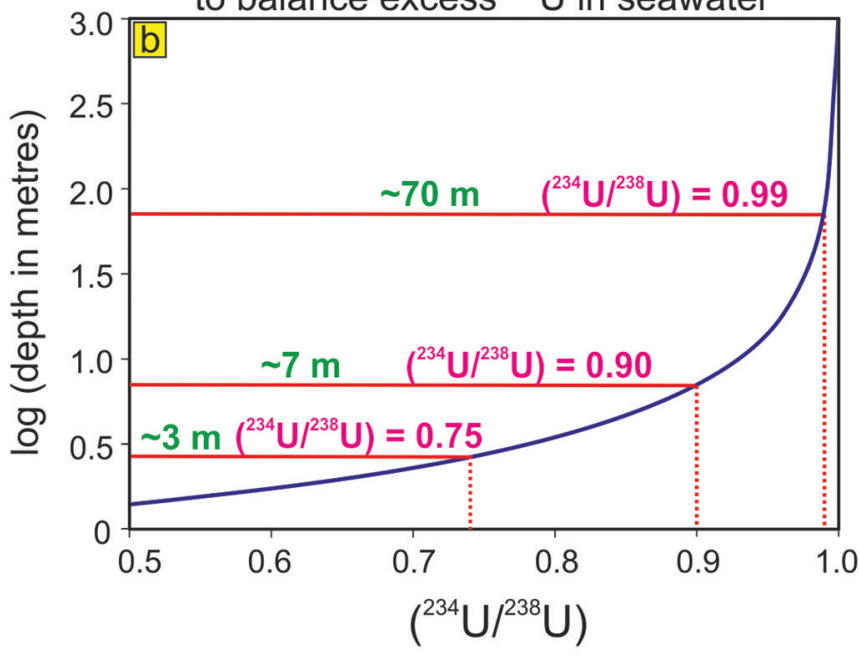

Deccan Trap weathering profile

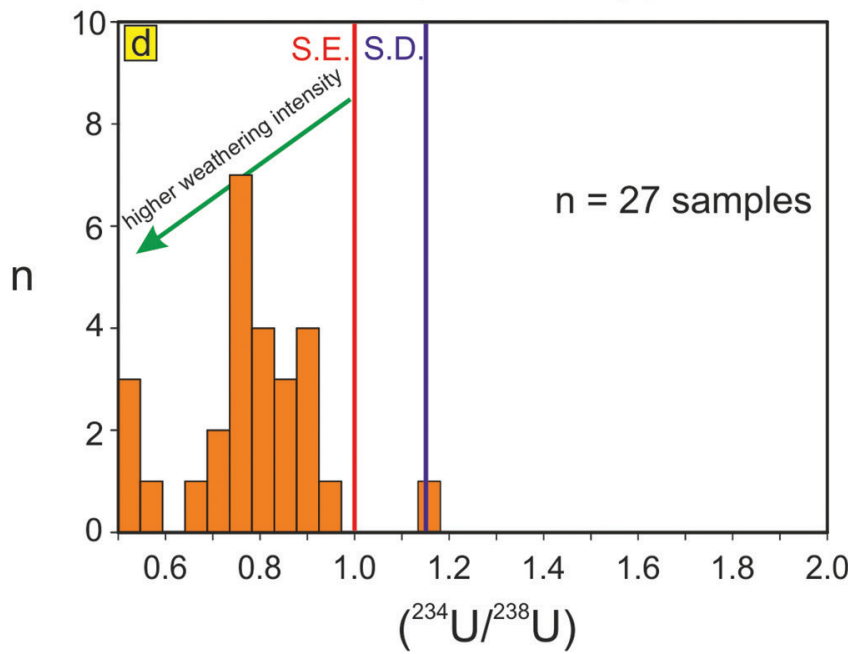

Figure 1 Histograms of $\left({ }^{234} U /{ }^{238} U\right)$. (a) Previously published data for weathering profiles. (b) Results of a simple mass balance calculation accounting for the observed ${ }^{234} \mathrm{U}$ excess in seawater in terms of weathering depth for various values of $\left({ }^{234} U /{ }^{238} U\right)$ in the residual weathered material. (c) Dissolved load in major rivers. (d) Weathering profile of this study. S.E. = secular equilibrium; S.D. = seawater dissolved $\left({ }^{234} \mathrm{U} /{ }^{238} \mathrm{U}\right)$. The average, median and standard deviation $(\sigma)$ of each respective data set are illustrated in $(\mathrm{a}, \mathrm{c})$. Data for $(\mathrm{a}, \mathrm{c})$ are compiled in Table S-1.

To describe the U cycle on the Earth's surface with a simple steady state model, it can be assumed that the seawater $\mathrm{U}$ inventory $\left(\mathrm{ca} .4 .7 \times 10^{15} \mathrm{~g}\right.$ ) must have been released from the continents. Additionally, the $\left({ }^{234} \mathrm{U} /{ }^{238} \mathrm{U}\right)$ ratio in seawater $(\sim 1.145)$ suggests that an excess of ca. $3.74 \times 10^{10} \mathrm{~g}$ of ${ }^{234} \mathrm{U}$ must be counterbalanced as a deficit on land. In our mass balance, $5.31 \times 10^{10} \mathrm{~g}$ of ${ }^{234} \mathrm{U}$ per metre depth are concentrated in the Earth's surface (the CZ) on average. Taking into account possible ranges in $\left({ }^{234} \mathrm{U} /{ }^{238} \mathrm{U}\right)$ of terrestrial weathering products (Table S-1; Fig. 1a) the average necessary depth of the weathering front can be calculated to balance the excess ${ }^{234} \mathrm{U}$ in seawater (Table S-2). The relationship between weathering depth and $\left({ }^{234} \mathrm{U} /{ }^{238} \mathrm{U}\right)$ is visualised on a binary plot (Fig. 1b). Accordingly, a global mean $\left({ }^{234} \mathrm{U} /{ }^{238} \mathrm{U}\right)$ of 0.99 would require an average weathering depth on Earth of $c a .70 \mathrm{~m}$. By contrast, if a $\left({ }^{234} \mathrm{U} /{ }^{238} \mathrm{U}\right)$ value of 0.90 is adopted as the representative value for residual weathered material, the required thickness reduces drastically to only $7 \mathrm{~m}$. Furthermore, a $\left({ }^{234} \mathrm{U} /{ }^{238} \mathrm{U}\right)$ value of 0.75 for the terrestrial weathering products would be balanced with a weathering front of less than $3 \mathrm{~m}$.

In view of the difficulty of reconciling the dissolved $U$ budget of the ocean (requiring a mean global CZ thickness of ca. $70 \mathrm{~m}$ ) with the observed mean $\mathrm{CZ}$ thickness of $c a .37 \mathrm{~m}$ (Xu and Liu, 2017), we here set out to test whether the solution to this discrepancy might be that the strongly weathered residue at the Earth's surface is underlain by a more actively weathering part of the $\mathrm{CZ}$ at greater depth, supplying $\mathrm{U}$ with a more severe ${ }^{234} \mathrm{U}$ deficit. This prospect prompted the investigation into the Th/U and $U$ series systematics of an active weathering profile where primary mineral alteration has not yet progressed to the levels of oxide and hydroxide formation typical of laterites. The studied saprolitic smectite-dominated profile developed across an active weathering front on Deccan Trap basalt protolith. It is exposed to $640 \mathrm{~cm}$ depth in an artisan quarry east of Chhindwara, India on the very top of a flat-lying mesa, thus minimising effects of lateral element transport with water. The sampling area is also not subjected to significant atmospheric dust inputs (Babechuk et al., 2015), and the lack of an excessive vegetation cover and biomass-dominated topsoil minimise the amount and effects of organic matter in the profile. The limited degree of weathering permits recognition of two basalt flows (Figs. 2, S-2), whose morphology, vesicularity and joint patterns have controlled the location and extent of weathering. As a result, the weathering intensity increases 


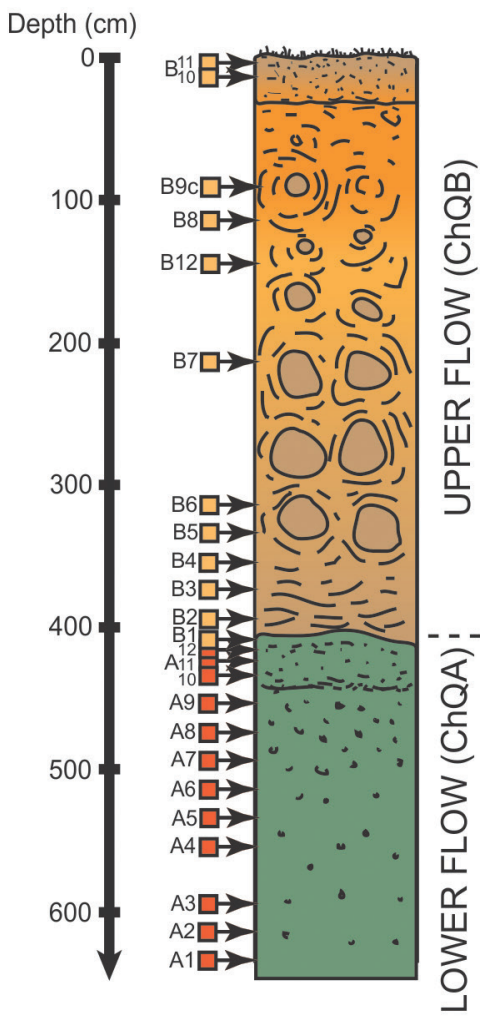

a

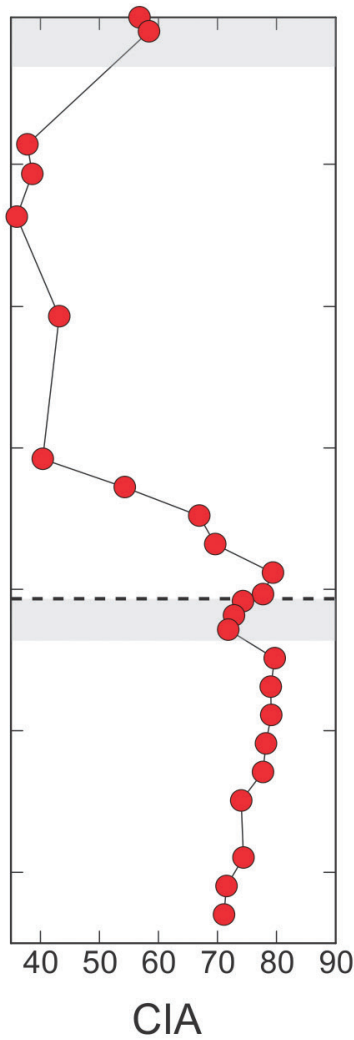

b

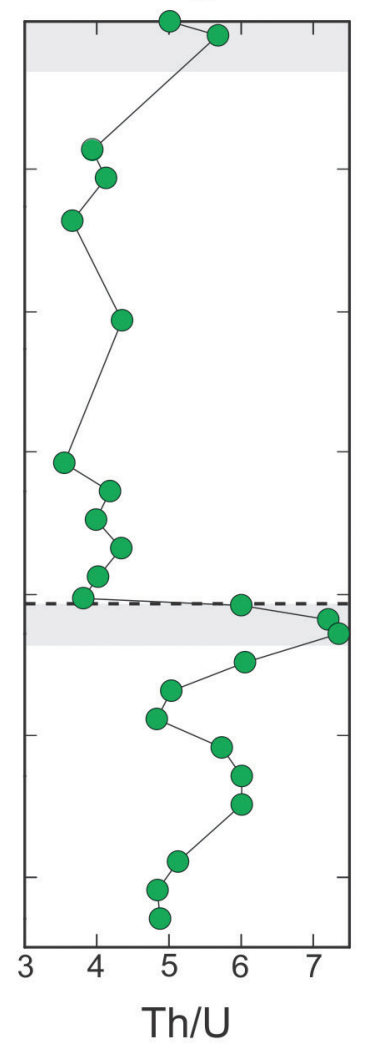

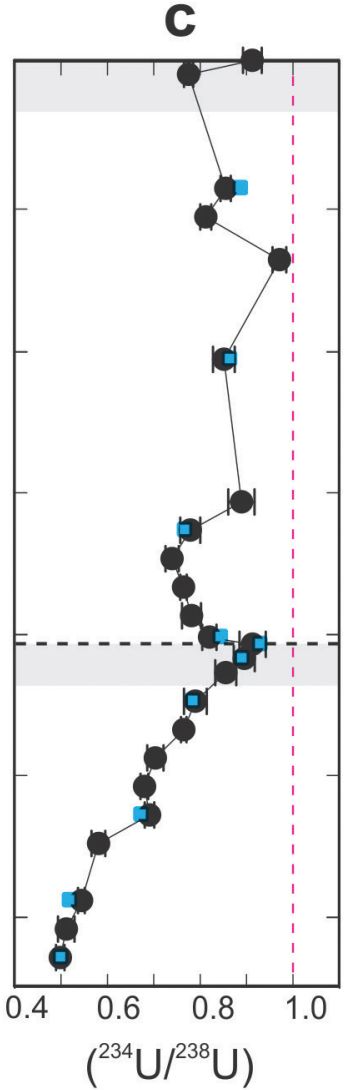

Figure 2 Vertical profile of volcanic flows and weathering characteristics. (a) CIA. (b) Th/U ratio. (c) (234U/238U), dashed purple line illustrates secular equilibrium, black dots = Q-ICP-MS data, blue squares = MC-ICP-MS data to test the accuracy of Q-ICP-MS data. Note that errors bars of MC-ICP-MS data are smaller than symbols; the contact between the two flows is shown on each plot as a horizontal dashed line. The modern soil surface and palaeo-flow surface are denoted by the horizontal shaded horizons.

downwards within the profile and remains relatively constant in the lower flow with Chemical Index of Alteration (CIA) values of 70-80. It, therefore, departs from simplified textbook examples of decreasing weathering intensity with depth. The profile has been the subject of very detailed earlier geochemical studies (Babechuk et al., 2014, 2015) in which sample context, mineralogy, geochemistry and weathering behaviour are documented. Here we analysed the same samples for $U$ series compositions (27 samples, including 4 samples from a corestone) with a quadrupole inductively coupled plasma mass spectrometer (Q-ICP-MS) and representative samples of both flows with a high precision multi collector inductively coupled plasma mass spectrometer (MC-ICP-MS).

\section{Correlation between Weathering Indices and U/Th}

Analytical methods and geochemical data, as well as additional descriptions of the weathering trends, are presented in the Supplementary Information and in Table S-3. To assess weathering intensity, weathered material was compared to two samples of least weathered parental rock (ChQB12, CHQB9c). Overall, the saprolitic profile has progressed to an intermediate weathering intensity (Fig. 2a), with CIA values ranging from 36 (fresh bedrock) to 80 (saprolite). Furthermore, nearly all samples show elevated Th/U ratios relative to the least weathered parent rock, indicating preferential elemental U release (Fig. 2b). Importantly, all weathered samples also demonstrate clear preferential ${ }^{234} \mathrm{U}$ loss, resulting in $\left({ }^{234} \mathrm{U} /{ }^{238} \mathrm{U}\right)$ well below unity (Fig. 2c), whereas the least weathered bedrock (ChQB12) has a $\left({ }^{234} \mathrm{U} /{ }^{238} \mathrm{U}\right)$ close to secular equilibrium (0.972). In the lower flow, $\left({ }^{234} \mathrm{U} /{ }^{238} \mathrm{U}\right)$ decreases quite smoothly from the top (0.914) towards the base (0.500). The preferential release of ${ }^{234} \mathrm{U}$ is strongly associated with loss of mobile over least mobile elements. For example, $\left({ }^{234} \mathrm{U} /{ }^{238} \mathrm{U}\right)$ and $\mathrm{Mg} / \mathrm{Ti}$ are strongly positively correlated $\left(\mathrm{r}^{2}=0.835\right.$; Fig. $\left.3 \mathrm{a}\right)$. Thus, the chemical breakdown of $\mathrm{Mg}$-silicates appears to occur concomitantly with the breakdown of glass and fine-grained matrix, resulting in the release of ${ }^{234} \mathrm{U}$. This observation was contextualised with trace element maps (Fig. S-3), showing that $U$ and Th are enriched in glass and matrix occurring as interstitial material and inclusions in silicate minerals. The phenocrysts apparently form a crystalline mineral barrier whose breakdown by weathering then promotes accelerated chemical dissolution of glass and matrix. In both flows, there is also an anti-correlation between $\left({ }^{234} \mathrm{U} /{ }^{238} \mathrm{U}\right)$ and $\mathrm{Fe}_{2} \mathrm{O}_{3}$ (Fig. 3b), and the association between elevated $\mathrm{Th} / \mathrm{U}$ and $\mathrm{Fe}_{2} \mathrm{O}_{3}$ identifies weathering intensity as the key control on $U$ loss and $U$ isotope systematics.

\section{Significance for the Dissolved Riverine $\mathrm{U}$ Flux and the Marine ${ }^{234} \mathrm{U}$ and $\mathrm{U}$ Inventories}

The profile demonstrates that ${ }^{234} \mathrm{U}$ was lost preferentially over lattice-bound U. This finding is in agreement with experimental leaching studies that predict that ${ }^{234} U$ should readily enter solutions because it resides in crystal defects caused by alpha recoil rather than bound within the crystal lattice (e.g., Kigoshi et al., 1971). These experimental observations provide the mechanism for observed ${ }^{234} \mathrm{U}$ excess in river waters (Dosseto et al., 2008a) and seawater (e.g., Chen et al., 1986) and explain why $\left({ }^{234} \mathrm{U} /{ }^{238} \mathrm{U}\right)$ values in the dissolved phases of the 

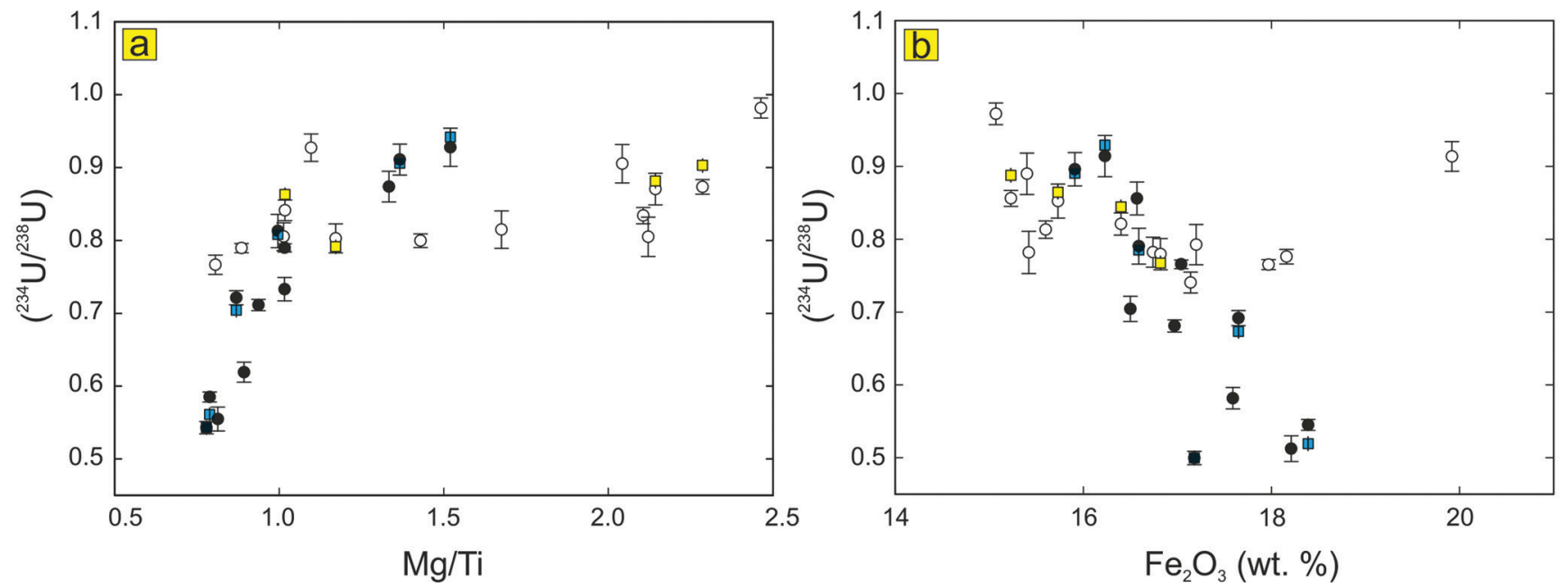

Figure $3 \mathrm{Bi}$-variate diagrams. (a) $\left({ }^{234} \mathrm{U} /{ }^{238} \mathrm{U}\right)$ vs. $\mathrm{Mg} / \mathrm{Ti}$. (b) $\left({ }^{234} \mathrm{U} / 238 \mathrm{U}\right)$ vs. $\mathrm{Fe}_{2} \mathrm{O}_{3}$. The decreasing $\mathrm{Mg} / \mathrm{Ti}$ ratios correlate with $\left({ }^{234} \mathrm{U} /{ }^{238} \mathrm{U}\right)$, whereas $\mathrm{Fe}_{2} \mathrm{O}_{3}$ anti-correlates.

Deccan rivers are significantly higher than secular equilibrium (from 1.1 to 1.3) (e.g., Vigier et al., 2005). The main finding from the new saprolite data is that a significant proportion of the ${ }^{234} \mathrm{U}$ excess in dissolved river loads could originate from saprolitic zones, occurring as deep incipient weathering fronts at the base of the CZ (Fig. 1).

To date, the only other studies that have documented strong loss of ${ }^{234} \mathrm{U}$ during weathering were performed on a thin soil profile developed on trachyte in Arizona (Rosholt et al., 1966) and across a soil-saprolite profile developed on a highly evolved Brazilian granite (Mathieu et al., 1995). In further agreement with these studies, our dataset suggests that ${ }^{234} \mathrm{U}$ loss was, at least on the scale of the entire profile, accompanied by elemental U loss. It may seem surprising that many earlier empirical studies have not unequivocally documented stronger ${ }^{234} \mathrm{U}$ and $\mathrm{U}$ deficits in weathering profiles. However, the average thickness of the $\mathrm{CZ}$ across continental areas lies at more than $35 \mathrm{~m}$ (Xu and Liu, 2017), and in tropical regions weathering profiles can be $>100 \mathrm{~m}$ thick (e.g., Buss et al., 2013). It is therefore likely that the zone of active weathering is often not readily accessible for sampling.

If the average $\mathrm{CZ}$ is composed of a narrow, actively weathering lower front and a more slowly weathering residue on top, their relative contributions to the marine ${ }^{234} \mathrm{U}$ can be calculated with relatively few assumptions. Taking an average global CZ of $36.8 \mathrm{~m}$ thickness, a $\left({ }^{234} \mathrm{U} /{ }^{238} \mathrm{U}\right)$ of $c a .0 .76$ in the actively weathering saprolite (samples from this study, $\mathrm{n}=25$; excluding the U-enriched corestone sample CHQB9d and least weathered parent rock $\mathrm{CHQB12})$ and $\left({ }^{234} \mathrm{U} /{ }^{238} \mathrm{U}\right)$ of $c a .0 .99$ in the more strongly weathered CZ ( $\mathrm{n}=335$; Fig. 1a,b; Tables S-1, S-2), the mass balance predicts that both layers contribute equally (ca. $50 \%$ ) to the oceanic ${ }^{234} \mathrm{U}$ excess (Fig. 4). In this model calculation, the resulting average $\mathrm{CZ}$ is composed of $1.45 \mathrm{~m}$ saprolite, and $35.35 \mathrm{~m}$ of previously reacted residue above; proportions that are consistent with field observations (Fig. S-4). In summary, the most parsimonious solution to the oceanic U inventory is that a very large pool of highly weathered $\mathrm{CZ}$ contributes roughly only half the $\mathrm{U}$ to the dissolved river load and the oceans, whereas a much narrower active zone of clay formation contributes the other half. In reality, there is a very strong longitudinal variability in CZ thickness and composition ( $\mathrm{Xu}$ and Liu, 2017) but until better U constraints from different climatic settings exist, the first order conclusion is that a volumetrically minor deep actively weathering $\mathrm{CZ}$ is disproportionally important for supplying elemental fluxes from the continents.
As might be expected from the relatively high standard deviation of the global mean $\left({ }^{234} \mathrm{U} /{ }^{238} \mathrm{U}\right)$, the elemental and isotopic systematics of Th and $\mathrm{U}$ are much more complex within the slowly weathering pool than in the saprolite (e.g., Dequincey et al., 2002; Dosseto et al., 2008b). Complexities arise from factors such as allochthonous input of $U$ (e.g., PettRidge et al., 2007) and Th (e.g., Pelt et al., 2013), biomass-related processes in topsoils (e.g., Rosholt et al., 1966), lateral U movement in down-hill topographies (e.g., Dosseto et al., 2008b) and formation of specific minerals, such as Fe-Al oxides (e.g., Engel et al., 2016). Oxyhydroxide-rich horizons, for example, promote complicated redistribution because Fe hydroxides can retain ${ }^{234} \mathrm{U}$ (e.g., Dequincey et al., 2002).

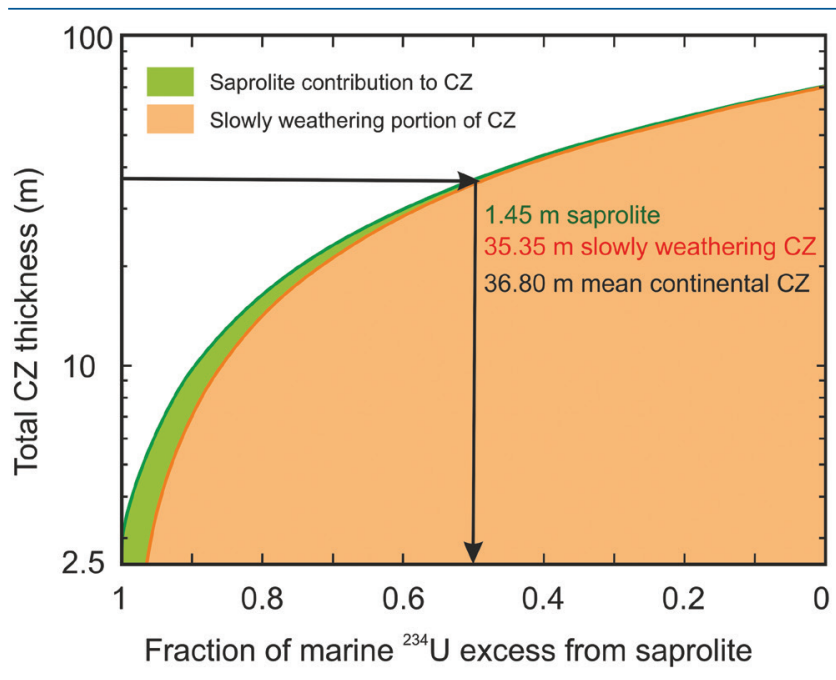

Figure 4 Total $\mathrm{CZ}$ thickness vs. fraction of marine ${ }^{234} \mathrm{U}$ excess from saprolite. For example, only $1.45 \mathrm{~m}$ of saprolite with $\left({ }^{234} \mathrm{U} /{ }^{238} \mathrm{U}\right)$ of ca. 0.76 is needed in steady state to contribute equally to the oceanic ${ }^{234} \mathrm{U}$ excess $(50 \%)$ as the more strongly weathered $C Z(35.35 \mathrm{~m})$ with $\left({ }^{234} \mathrm{U} / 238 \mathrm{U}\right)$ of ca. 0.99 .

Land surfaces in the tropics often consist of highly weathered and very old substrates, such as laterites which, on average, contain U close to secular equilibrium (Dequincey et al., 2002). In part, this is the result of the relatively short (246 kyr) half-life of ${ }^{234} \mathrm{U}$ (e.g., Dosseto, 2014), meaning that ${ }^{234} \mathrm{U}$ in the residuum of long-lived weathering profiles could return towards secular equilibrium with its parent nuclide $\left({ }^{238} U\right)$ in less than 2 Myr. Furthermore, it is known that the bulk of the mobile elements and their isotopic signals have long been lost 
from laterites (e.g., Babechuk et al., 2015), and that they typically make a limited contribution to the present dissolved load of rivers. By contrast, the strongly weathered residue can still contribute a significant fraction of the suspended load (Table S-1; Fig. S-5), as also suggested from Sr isotope systematics (e.g., Allègre et al., 1996).

\section{Conclusions}

The continental dissolved flux of waters draining active weathering fronts of Deccan basalt are distinguished by elevated $\left({ }^{234} \mathrm{U} /{ }^{238} \mathrm{U}\right)$, thus leaving behind a residual ${ }^{234} \mathrm{U}$-depleted residue. The calculated average $\left({ }^{234} \mathrm{U} /{ }^{238} \mathrm{U}\right)$ activity ratio of $c a$. 0.76 in this study for saprolite combined with mass balance calculations (Figs. 1b, 4; Table S-2) suggests that active weathering fronts within the deeper $\mathrm{CZ}$ are crucial to understanding the global U systematics. These fronts supply disproportionally high amounts of dissolved elements (Buss et al., 2013; and references therein), including $U$ (e.g., Ma et al., 2010), to the hydrosphere. The proposed scenario is corroborated by previously documented strong ${ }^{234} \mathrm{U}$ loss from weathering profiles (Rosholt et al., 1966; Mathieu et al., 1995) and suggests that the compiled global mean $\left({ }^{234} \mathrm{U} /{ }^{238} \mathrm{U}\right)$ of $0.992 \pm 0.096(1 \sigma ; n=335$ samples) (Fig. 1a) for weathering residue is not fully representative. We propose that the discrepancy is due to the relative inaccessibility of the thin active (saprolitic) weathering zone at the rock-soil interface, having caused a sampling bias in favour of highly weathered residuum in many previous studies. Accordingly, the model envisaged here differs from the previous implicit assumption that a voluminous zone within the upper parts of the Earth surface dominantly supplies $U$ to rivers and oceans. Our new data show that on the Deccan Traps basalts, strong preferential release of ${ }^{234} \mathrm{U}$ is restricted to relatively thin weathering zones of saprolite where primary minerals weather to clays close to the rock-soil interface. There, the significant isotopic fractionation processes of $U$ predicted by experiments are related to the preferential breakdown of glass and matrix. The study of elemental and stable isotope ratio systematics of other redox-sensitive elements (e.g., $\mathrm{Mo}, \mathrm{Cr}, \mathrm{Fe}$, S, Zn; e.g., Suhr et al., 2018; Wille et al., 2018) can benefit from focussing on comparable active weathering zones similarly exhibiting the $U$ deficits required by mass balance, because the hydro-bio-geochemical cycles of these elements are known to have been affected by free oxygen in the atmosphere since the Precambrian (e.g., Bekker et al., 2004; Partin et al., 2013). Once the behaviour of these elements has been documented, deeper time studies can build on the new insights and help to reconstruct ancient Earth surface processes and associated ocean chemistry evolution.

\section{Acknowledgements}

This research is the contribution of the ISONOSE Marie Curie Research training network (www.IsoNose.eu) funded from the People Programme (Marie Curie Actions) of the European Union's Seventh Framework Programme FP7/2007-2013/ under REA grant agreement $n^{\circ}$ [608069]. We thank Cora McKenna for help during laboratory work and Michael Murphy at UCD for assistance during MC-ICP-MS analysis. We thank Dr David Chew for making the LA-ICP-MS trace element maps and four anonymous reviewers for their critical comments.

Editor: Eric Oelkers

\section{Additional Information}

Supplementary Information accompanies this letter at http:// www.geochemicalperspectivesletters.org/article1803.

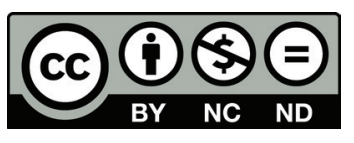

This work is distributed under the Creative Commons Attribution Non-Commercial No-Derivatives 4.0 License, which permits unrestricted distribution provided the original author and source are credited. The material may not be adapted (remixed, transformed or built upon) or used for commercial purposes without written permission from the author. Additional information is available at http://www.geochemicalperspectivesletters.org/ copyright-and-permissions.

Cite this letter as: Suhr, N., Widdowson, M., McDermott, F., Kamber, B.S. (2018) Th/U and U series systematics of saprolite: importance for the oceanic $234 \mathrm{U}$ excess. Geochem. Persp. Let. $6,17-22$

\section{References}

Allègre, C.J., Dupré, B., Négrel, P., Gaillardet, J. (1996) Sr-Nd-Pb isotope systematics in Amazon and Congo River systems: constraints about erosion processes. Chemical Geology 131, 93-112.

BABEchuK, M.G., Widdowson, M., KAMBER, B.S. (2014) Quantifying chemical weathering intensity and trace element release from two contrasting basalt profiles, Deccan Traps, India. Chemical Geology 363, 56-75.

BABEchuK, M.G., Widdowson, M., Murphy, M., Kamber, B.S. (2015) A combined $\mathrm{Y} / \mathrm{Ho}$, high field strength element (HFSE) and $\mathrm{Nd}$ isotope perspective on basalt weathering, Deccan Traps, India. Chemical Geology 396, 25-41.

Bekker, A., Holland, H.D., Wang, P.L., Rumble, D., Stein, H.J., Hannah, J.L., Coetzee, L.L., Beukes, N.J. (2004) Dating the rise of atmospheric oxygen. Nature 427, 117-120.

Buss, H.L., Brantley, S.L., Scatena, F., Bazilievskaya, E., Blum, A., Schulz, M., Jiménez, R., White, A.F., Rother, G., Cole, D. (2013) Probing the deep critical zone beneath the Luquillo Experimental Forest, Puerto Rico. Earth Surface Processes and Landforms 38, $1170-1186$.

Chabaux, F., Riotte, J., Clauer, N., France-Lanord, C. (2001) Isotopic tracing of the dissolved $U$ fluxes of Himalayan rivers: implications for present and past $U$ budgets of the Ganges-Brahmaputra system. Geochimica et Cosmochimica Acta 65, 3201-3217.

Chen, J., Edwards, R.L., WasserburG, G. (1986) 238 U, 234 U and 232 Th in seawater. Earth and Planetary Science Letters 80, 241-251.

Dequincey, O., Chabaux, F., Clauer, N., Sigmarsson, O., Liewig, N., LEPRUN, J.C. (2002) Chemical mobilizations in laterites: evidence from trace elements and 238U-234U-230Th disequilibria. Geochimica et Cosmochimica Acta 66, 1197-1210

Dosseto, A. (2014) Chemical Weathering (U-Series). In: Rink, W.J., Thompson, J. (Eds.) Encyclopedia of Scientific Dating Methods. Springer Netherlands, Dordrecht, 1-28.

Dosseto, A., Bourdon, B., Turner, S.P. (2008a) Uranium-series isotopes in river materials: Insights into the timescales of erosion and sediment transport. Earth and Planetary Science Letters 265, 1-17.

Dosseto, A., Turner, S.P., CHAPPELl, J. (2008b) The evolution of weathering profiles through time: New insights from uranium-series isotopes. Earth and Planetary Science Letters 274, 359-371.

DunK, R.M., Mills, R.A., Jenkins, W.J., (2002) A reevaluation of the oceanic uranium budget for the Holocene. Chemical Geology 190, 45-67.

Engel, J.M., Ma, L., SaK, P.B., Gaillardet, J., Ren, M., Engle, M.A., BRANTLEY, S.L. (2016) Quantifying chemical weathering rates along a precipitation gradient on Basse-Terre Island, French Guadeloupe: New insight from U-series isotopes in weathering rinds. Geochimica et Cosmochimica Acta 195, 29-67.

Henderson, G.M. (2002) Seawater $\left({ }^{234} \mathrm{U} /{ }^{238} \mathrm{U}\right)$ during the last 800 thousand years. Earth and Planetary Science Letters 199, 97-110.

Kigoshi, K. (1971) Alpha-Recoil Thorium-234: Dissolution into Water and the Uranium-234/Uranium-238 Disequilibrium in Nature. Science 173, 47-48. 
Mathieu, D., Bernat, M., NAHON, D. (1995) Short-lived U and Th isotope distribution in a tropical laterite derived from granite (Pitinga river basin, Amazonia, Brazil): Application to assessment of weathering rate. Earth and Planetary Science Letters 136, 703-714.

Ma, L., Chabaux, F., Pelt, E., Blaes, E., Jin, L., Brantley, S. (2010) Regolith production rates calculated with uranium-series isotopes at Susquehanna/Shale Hills Critical Zone Observatory. Earth and Planetary Science Letters 297, 211-225.

Partin, C.A., Bekker, A., Planavsky, N.J., Scott, C.T., Gill, B.C., Li, C., Podkovyrov, V., Maslov, A., Konhauser, K.O., Lalonde, S.V., Love, G.D., Poulton, S.W., Lyons, T.W. (2013) Large-scale fluctuations in Precambrian atmospheric and oceanic oxygen levels from the record of $\mathrm{U}$ in shales. Earth and Planetary Science Letters 369-370, 284-293.

Pelt, E., Chabaux, F., Stille, P., Innocent, C., Ghaleb, B., Gérard, M., Guntzer, F. (2013) Atmospheric dust contribution to the budget of $\mathrm{U}$-series nuclides in soils from the Mount Cameroon volcano. Chemical Geology 341, 147-157.

Pett-Ridge, J.C., Monastra, V.M., Derry, L.A., Chadwick, O.A. (2007) Importance of atmospheric inputs and Fe-oxides in controlling soil uranium budgets and behavior along a Hawaiian chronosequence. Chemical Geology 244, 691-707.

Rosholt, J.N., Doe, B.R., Tatsumoto, M. (1966) Evolution of the isotopic composition of uranium and thorium in soil profiles. Bulletin of the Geological Society of America 77, 987-1004.

Suhr, N., Schoenberg, R., Chew, D., Rosca, C., Widdowson, M., KAMBER, B.S. (2018) Elemental and isotopic behaviour of $\mathrm{Zn}$ in Deccan basalt weathering profiles: Chemical weathering from bedrock to laterite and links to $\mathrm{Zn}$ deficiency in tropical soils. Science of The Total Environment 619-620, 1451-1463.

Vigier, N., Bourdon, B., Lewin, E., Dupré, B., Turner, S., Chakrapani, G., Van Calsteren, P., Allègre, C. (2005) Mobility of U-series nuclides during basalt weathering: an example from the Deccan Traps (India). Chemical Geology 219, 69-91.

Wille, M., Babechuk, M.G., Kleinhanns, I.C., Stegmaier, J., Suhr, N., Widdowson, M., Kamber, B.S., Schoenberg, R. (2018) Silicon and chromium stable isotopic systematics during basalt weathering and lateritisation: A comparison of variably weathered basalt profiles in the Deccan Traps, India. Geoderma 314, 190-204.

XU, X., LIU, W. (2017) The global distribution of Earth's critical zone and its controlling factors. Geophysical Research Letters 44, 3201-3208. 